\title{
NOVÉ TRENDY VE VYUČOVÁNÍ KULTUŘE
}

\author{
Krystyna Heinz, Irena Orszulik
}

\section{Klíčová slova:}

postmodernismus, jazyk hodnot, pragmatika, interkulturní kompetence, interakce, zdvořilost, kultura, kulturní hodnoty, etika, empatie, vyučování kultuře, kurz Personal Development Skills for Mobilities

\section{Key words:}

postmodernism, language of values, pragmatics, intercultural competence, interaction, politeness, culture, culture values, course Personal Development Skills for Mobilities, ethics, empathy, teaching culture

\begin{abstract}
Abstrakt
Článek se zabývá rolí interkulturní kompetence a vyučováním kultuře v období postmodernismu. V první části uvádí vývoj interkulturní kompetence v různých kulturách, další část je věnovaná pragmatickému pohledu na interkulturní problematiku s důrazem na kulturní hodnoty, etiku, zdvořilost, rozvíjení empatie a nové trendy ve vyučování kultuře. Uvádí nově vytvořený kurz Personal Development Skills for Mobilities, který bude součástí kurikula na OPF SU v Karviné.
\end{abstract}

\begin{abstract}
The article focuses on the role of intercultural competence and teaching culture in the era related to postmodernism. In the first part it presents the development of intercultural competence in various cultures, the other parts are devoted to the pragmatic view of some intercultural issues with the culture values, ethics, emphasis on expressing politeness, developing empathy, and listing new trends in teaching culture. It introduces a newly developed course Personal Development Skills for Mobilities which will become part of the curriculum at School of Business Administration in Karviná.
\end{abstract}

\section{Úvod}

Komunikace v multikulturním světě vyžaduje znalosti, postoje a dovednosti týkající se interkulturní interakce, tj. vytváření lingvistického, sociolingvistického, pragmatického a kulturního povědomí. Účastníci komunikace by měli mít schopnost umístit danou komunikační situaci v kontextu, uvědomit si vlastní ideologické perspektivy a kulturní hodnoty, a také mít povědomí potencionálního konfliktu a schopnost vyjednávat a akceptovat odlišnosti.

Soudobá společnost je zmítána kulturními a ekonomickými a změnami. Po zhroucení myšlení a kultury v moderní éře nastupuje nová epocha - postmodernismus, který, ačkoliv zahrnuje mnoho dimenzí, jednoznačně označuje konec jednotného, univerzálního pohledu na svět. Postmodernismus jako kulturní jev vznikl v letech 1960-1990. Jeho příchod je spojován především s prríchodem informační éry a statistické údaje o struktuře zaměstnanosti dokazují, že společnost prožívá přechod od industriální společnosti k společnosti informační. Věk informatiky způsobil existenci globální obce, jejíž obyvatelé si uvědomují existenci kulturní různorodosti světa, která vybízí k pluralistickému postoji. Postmoderní étos je 
charakterizován úctou k rozdílnosti a upřednostňováním místního a jednotlivého na úkor univerzálního. Odmítá důraz na rozumnost a označuje intelektuální rozpoložení celou řadu kulturních projevů, které zpochybňují ideály, principy a hodnoty, tvořící podstatu moderního postoje.

Postmoderní vědomí se charakterizováno hledáním modelu spolupráce a smyslu pro jiné než rozumové dimenze pravdy, což dodává postmodernímu vědomí holistický rozměr znamenající integraci citové, intuitivní a poznávací složky života. Postmoderní vědomí s sebou nese radikální typ relativismu a pluralismu, který se zaměřuje na skupinu, z nichž každá má svůj vlastní jazyk, názory a hodnoty. Př́slušníci těchto skupin nemusejí dokazovat, že jejich názory jsou správné, zatímco názory druhých jsou chybné, ale domnívají se, že přesvědčení je otázkou společenského kontextu a přijatelnost nebo nepřijatelnost něčeho závisí na konkrétní situaci. Nutnost široce pojímané tolerance, která z výše uvedeného vyplývá, ovlivňuje také pojetí interkulturní kompetence a vyučování kultuře[3].

\section{Interkulturní kompetence $\mathrm{z}$ hlediska některých národních kultur}

Rozvoj interkulturní kompetence by měl mít na zřeteli rozvíjení flexibility a adaptibility a tolerance k jiným jazykům a kulturám. Nový přístup také zahrnuje schopnost analyzovat svou vlastní kulturu a provádět její srovnávání s jinými kulturami.

V několika posledních desetiletích se komunikační trénink v rámci vyučování interkulturní komunikace stal jedním z nejatraktivnějších produktů cizojazyčné komunikace nabízených studentům. Interkulturní trénink[5] rozvíjí interkulturní povědomí studentů i učitelů a posiluje jejich citlivost na různé, někdy i protichůdné stránky kulturní diverzity. V kurzech interkulturní komunikace jsou zprostředkovávány přímé zkušenosti vyplývající z kontaktu s cizí kulturou.

Interkulturní kompetence je nepostradatelnou částí sociální kompetence mezinárodních manažerů, kteří se ve své práci přímo setkávají s př́íslušníky cizích kultur. Je to schopnost vstupovat do interkulturních nebo multikuturních situací, pochopit je ve všech kulturních dimenzích, přiměřeně je zvládat a v jejich kontextu úspěšně řešit věcné úkoly. Interkulturní kompetence může být dosaženo vlastní iniciativou jedince, který je schopen orientovat se v jakýchkoli sociálních situacích a zobecnit konkrétní kulturní odlišnosti, nebo formou interkulturního tréninku, který je zaměřen na hlubší poznání a pochopení kulturních standardů.

Je všeobecně známo, že začátky zájmu o interkulturní komunikaci jsou patrné ve Spojených státech a spadají do konce 40. a začátku 50. let. Hlavním důvodem je nutnost spolužití př́slušníků různých etnických skupin v důsledků imigračního procesu. Antropologové a psychologové, jako Hall a Birdwhistell věnovali pozornost zvláště neverbální složce komunikace a její transkulturní dimenzi. V této době byl Birdwhistellem [1] vytvořen imfrakomunikační model zahrnující kromě tradičního audio-akustického kanálu také kanál kinezický, proxemický, chronemický, haptický a paralingvistický. Hall [4] je autorem hierarchické struktury v rámci kineziky a zavedl pojmy, jako kiném, kinemorfém, atd.

Zajímavé je sledovat nejednoduchou cestu k pojetí interkulturní kompetenci v různých národních kulturách. Velmi složitou cestou musela projít ruská kultura její postoj k interkuturní kompetenci, a hlavně přehodnocení postoje z doby sovětské. Po roce 1990 se 
začaly objevovat publikace dvou známých lingvistů - Kostomarova a Vereščagina [12,18], kteří se i v sovětské době zabývali problematikou kultury $\mathrm{v}$ rámci tak zvaného „lingvostranovedenija“. V roce 1994 tito autoři přiznávají, že v sovětské době „lingvostranovedenije“ používalo pouze informace o pozitivních stránkách života, a proto je nutné tento obor $\mathrm{v}$ nových podmínkách kvalitativně obměnit, zvláště je zapotřebí používat multidisciplinární přístup, ruská kultura má být sledována $\mathrm{v}$ kontextu evropských národů slovanských i neslovanských, evropských i dalších $\mathrm{v}$ kontrastivním plánu, je třeba brát v úvahu proxemické a chronemické charakteristiky kultur a také věnovat pozornost jazykovým kontaktům a jevům bilingvismu a bikulturalismu.

V publikaci z roku 1999 stejní autoři vycházejí z teorie řečových aktů, věnují se oblastem viny, hříchu a pokuty $\mathrm{v}$ ruské duchovní kultuře. Domnívají, že tyto skutečnosti zaujímají centrální místo a mají dopad na komunikaci s Rusy a projevují se jak v oblasti řečových aktů, tak v oblasti chování. Je dán výčet taktik v oblasti řečové i chování typických pro ruskou realitu v synchronním i diachronním plánu. Jako příklad je uvedeno rčení typické pro starší generaci intelektuálů - "Govorit' o den'gach neprilično". Diskuse týkající se peněžních záležitostí měla konotaci netaktnosti, nevzdělanosti, hrubosti, povrchnosti a dokonce nedůstojnosti. V podmínkách nového rodícího se kapitalismu se o penězích běžně mluví mezi podnikateli, v rodinách a v každodenní konverzaci. Diskutuje se o tom, jak se vyhnout daním, a o jiných věcech, které by byla kdysi považovány za spekulace. Kdysi platila zásada, že peníze jsou zlo, tuto skutečnost dokládají mnohá př́ísloví:"Ne v den'gach sčastie, Uma za den'gi ne kupiš, Ne s den'gami žit,'a s dobrymi ljud'mi. V minulém režimu byly ceny uměle drženy na nízké úrovni, ale lidé dostávali pravidelně platy a kupní síla byla vysoká. Některé druhy zboží byly deficitní, a proto bylo třeba mít známosti.

V dnešní době peníze znamenají dobro. Staré sentence byly změněny. Místo" Ne imej 100 rublej, a 100 druzej" se nyní ŕíká " Ne imej 100 rublej, a 10000 rublej" nebo "Bednost' ne porok, a bol`šoje svinstvo". Změnil se také vztah k lidem, kteří mají špinavé peníze - lidé je sledují se sympatiemi a s obdivem. Výše uvedené taktiky nejsou stabilní, mohou se změnit. Kolektivní mentální změna norem a hodnocení se uskutečňuje u mladých lidí rychleji, starší jsou konzervativnější.

V dnešní době v Turecku jsou na akademické půdě vedeny diskuse týkající se přehodnocení pojmu komunikativní kompetence směrem k interkulturní kompetenci a uznání postavení angličtiny v pozici „lingua franca“ v tureckých podmínkách. Ačkoliv celonárodní diskuse odhalila značné názorové rozdíly, v tom dokonce extrémní požadavky na ukončení vyučování angličtiny na středních školách, významní turečtí akademici se domnívají, že v 21.století angličtina bude jazykem mezinárodní komunikace a je tedy nezbytné hovořit o bilingvních nerodilých mluvčích než o rodilých mluvčích, kteří se budou pohybovat na hranici mezi dvěma jazyky. Pojem „native speaker“ je na ústupu a bude nahrazen termínem ,proficient user of English“. Existuje nutnost vytvořit nový model komunikativní kompetence $\mathrm{v}$ tureckém prostředí, který by měl obsahovat postuláty, jako úspěšný bilingvní mluvčí vybaven interkulturním povědomím, dostupnost materiálů pro výuku anglického jazyka zahrnující interkulturní kontext, tj. schopnost komunikovat zároveň ve vztahu rodilýnerodilý mluvčí a nerodilý a nerodilý mluvčí, a znalost vlastního i cizího kulturního zázemí.

V souvislosti s možným vstupem Turecka do EU věnována pozornost tematice národní identity. S cílem zjistit postoje tureckých studentů na partnerské Onsekiz Mart University v Canakkale a také českých studenti̊ na OPF SU v Karviné byl v roce 2009 uskutečněn dotazníkový výzkum. Česká část výzkumu byla zaměřena na skutečnosti související se 
vstupem Turecka do EU a jeho možným dopadem - pozitivním i negativním. Výzkum ukázal, že čeští studenti ve svých odpovědích prezentovali jak pozitivní tak negativní postoje, avšak často vyslovovali názor, že turecká kultura a náboženství se podstatně liší od evropských kulturních hodnot a že Turci by museli čelit problémům týkajícím se adaptace na evropské zvyky a evropská pravidla.

\section{Kulturní hodnoty a jejich odraz $\mathbf{v}$ jazyce}

Je zřejmé, že jazyk odráží způsob myšlení určité kultury a je důležitým faktorem při zprostředkování kulturních hodnot a dimenzí. Snad ve všech jazycích lze najít pojmenování, která vyjadřují vztahy uživatelů k sousedním státům, národům nebo etnikům. Některá z nich mají doloženou etymologii i domnělou historickou situaci, ve které vznikla. Vedle neutrálních slovních spojení existuje celá řada expresivních slovních spojení, do kterých se promítá kladné či pejorativní hodnocení mluvčích v souvislosti s přátelským nebo xenofobním postojem.

V německém prostředí je kodifikováno např. spojení „,böhmisches Dorf, böhmische Dörfer, es kommt mir böhmisch vor"/španělská vesnice, připadá mi to podivné / ve významu něco jiného, odlišného, podivného. Může mít i pejorativní konotace., synonymum nepořádku a chaosu. Podobně jako v češtině spojení „turecké hospodářství“, které konotuje expresívní významy ve smyslu přetvářky, podfuku, nepořádku. V němčině lze nalézt ekvivalent s podobným významem „etwas türkt, einen Turken bauen“, který je expresívní povahy a znamená něco předstírat, prezentovat falsifikát namísto originálu, klamat.

Obdobnou historickou zkušenost, která se odráží v jazyce, lze doložit v češtině i v polštině. V češtině i v polštině se objevuje stejný idiom, který v němčině nebyl nalezen ,poturčenec horší Turka“"“ poturczeniec gorszy Turka“. Spojení má expresívní povahu, znamená, že se jedná o odpadlíka, který kvůli výhodě stojí na straně nepřítele.

Kulturní rozdíly $\mathrm{v}$ interakci mezi prŕíslušníky různých národů lze ukázat rovněž na následujícím př́kladu. Ve smyslu zmizet nepozorovaně, nenápadně, možná i nezdvořile používá čeština i polština přirovnání k angličanů: “zmizet po anglicku“, „wyjść po angielsku, wymknac sie po angielsku“. Němčina má v tomto kontextu doloženo přirovnání ke svým geograficky bližším sousedům-Francouzům,,sich auf französisch verabschieden“," auf französische Art verschwinden“- Konotace: rozloučit se nezdvořile, kvapně, vytratit se. Zřjejmě sociokulturní pozadí má spojení, „, dře, maká jako Bulhar, Slovák“, znamená těžce pracovat, pracovat jako negr, černý, otrok. Zřejmě souvisí s příznakem identifikace. V německém prostředí lze najít v tomto významu frazeologická spojení v souvislosti s tureckými emigranty. Např.:,Arbeiten als Kümmeltürke“- pejorativní označení. [14].

Jazyk a kultura, jak již bylo zmíněno, vzájemně souvisí. Idiomy a frazeologická spojení např́íč různými jazyky jednoznačně dokumentují mezikulturní vztahy. Odkazuje to na skutečnost, že jazyk úzce souvisí s myšlením, kulturou a historii daného společenství. Předpokládáme, že bude docházet k intenzifikaci vzájemných jazykových vlivů, a to nejen ve směru dominantní angličtiny, nýbrž právě v oblasti „,sousedních jazyků“. Unifikace nepřispívá kultivaci a obohacování jazyka. Doufáme, že oba trendy, unifikace i diversifikace, budou existovat vedle sebe jako zdroj inovací ve frazeologii v jednotlivých jazycích[15]. 
Jazyk je pojímán jako jeden z nejdůležitějších znaků každého národa a je nedílnou součástí kultury. I když nemusí beze zbytku platit, že jazykové rozdíly znamenají zásadní rozdíly ve sféře kultury / např. Švýcarsko, Belgie/, přesto jsou velmi častým zdrojem netolerance napětí /Španělsko-Baskovél. Je zřejmé, že pokud známe jazyky naších nejbližších sousedů, partnerů v jednání, nebo alespoň máme snahu se jim v nějaké míre naučit, vytváříme tak optimální podmínky ke vzájemnému pochopení, poznání a toleranci. Lépe se rovněž daří proces adaptace $\mathrm{v}$ cílové kultuře.

Kulturní hodnoty typické pro danou kulturu mohou být reflektovány ve výrazových prostředcích. K nim naprríklad patří v angličtině způsob odkazu na svou vlastní zemi z externího pohledu. V angličtině slovní spojení „this country“ by nemohlo být použito ve vztahu k Polsku nebo polskému národu a indikuje pouze Velkou Británii. Naopak polština nebo čeština dává přednost spojení posesívního zájmena a podstatného jména - nasz kraj, nasz naród, naše země, náš národ“. Tento způsob vyjadřování naopak z pohledu anglicky mluvícího jedince znamená př́ilišné používání posesívních zájmen a je podnětem pro četné otázky anglických a amerických lektorů, kteří v České republice působí.

Zdvořilost v Polsku je manifestována také způsobem oslovení a neverbálními prostředky, hlavně políbením ruky. Poláci rádi používají v oslovení tituly, avšak není to projev ponižování, ale naopak vyjádření respektu a úcty. Tento respekt může být kombinován se srdečností, např́íklad v oslovení „pani Basieńko“. Ruština také disponuje mnohými prostředky pro demonstraci emocí, avšak pro rodilého mluvčího ruštiny není přirozené spojení emocí s formální situací. V ruštině se pro vyjádření respektu a úcty používá křestní jméno a jméno po otci, která se nemohou spojovat s deminutivy. Ruština podobně jako čeština má dva základní tvary oslovení - ty a vy, zatímco se v polštině nevyskytuje v současné době vy a používá se „,pan/pani“. Tvar „wy“ byl v polštině typický pro komunistickou éru a byl často spojován s neosobním apelativem ,towarzyszu, obywatelu“.

Srdečnost - emoce, se kterou se lze setkat v slovanských a středozemních kulturách, se odráží v bohatém systému expresívních derivací. V polštině, například, se vyskytuje celá řada emocionálních derivací vlastních jmen, které implikují rozdílné emocionální postoje, avšak se zachováním respektu vůči dané osobě - „Marysia, Marysieńka, Maryciuchna, Marycha“, atd. Oproti tomu anglosaská kultura neakceptuje demonstraci emocí, kromě deminutivních derivací souvisejících s dětmi a jejich hračkami, a polskému mluvčímu může připadat studená, nespontánní a neupřímná[6].

\section{Kultura a etika}

Kultura a etika jsou pojmy, které vzájemně úzce souvisí. Každá definice kultury se snaží vymezit pojem hodnot relevantních pro dané společenství. Etika pak znamená aplikaci norem, hodnot, zkušeností a způsobů chování entity v daném kulturním prostředí. Hodnoty jsou považovány za všeobecné tendence dávající přednost určitým stavům před jinými. Většinou bývají osvojovány v ranném dětství a většina lidí si jich není explicitně vědomá. Systém hodnot se dá zjistit pozorováním chování a jednání lidí. Sdělování hodnot probíhá různými způsoby, ne vždy verbálně. Samožrejmě verbální komunikace zde odehrává zásadní roli. Nejenom ve výchovném procesu, nýbrž po celý lidský život formulujeme soudy /hodnotící výpovědi/ z hlediska různých situací, potřeb a cílů. Tak jako dítě je uváděno do světa hodnot předurčenými dospělými, tak i dospělí se ve svém životě setkávají s celou řadou hodnotových systémů a hierarchií hodnot[16]. 
Za hodnoty v etice jsou považovány myšlenky, představy, koncepty, které nabývají z hlediska určité lidské potřeby význam. Realita, která člověka po celý jeho život provází, je realitou hodnot. Malé dítě, aniž by si bylo vědomo svých hodnotových kriterií, má vyvinutou na bázi smyslového vnímání, intuice a instinktu rozlišovací schopnost mezi tím, co mu prospívá ,„činí ho št’astným“ a tím, co mu škodí neuspokojuje jeho potřebu „být št’astným“. Když si dítě postupně osvojuje jazyk, je seznamováno se způsoby hodnocení reality i systémy hodnot. Sdělování hodnot probíhá různými způsoby, ne vždy verbálně. Samozř̉ejmě verbální komunikace zde odehrává zásadní roli. Nejenom ve výchovném procesu, nýbrž po celý lidský život formulujeme soudy /hodnotící výpovědi/ z hlediska různých situací, potřeb a cílů. Tak jako dítě je uváděno do světa hodnot předurčenými dospělými, tak i dospělí se ve svém životě setkávají s celou řadou hodnotových systému a hierarchií hodnot.

Jsme si vědomi toho, že hodnocení je prvkem subjektivní povahy. Rozdíly v používaní a prìřazování hodnotících prvků $\mathrm{v}$ jazyce souvisí s různým individuálním prrístupem k hodnotám, s rozdílnými hodnotovými systémy, které mají své kořeny ve filozofických východiscích, náboženství, kultuře, jazykovém povědomí, tradicích, sociálních podmínkách aj.

Různé přístupy v pojetí etiky se dají shrnout do dvou filozofických názorů. Jedním je tzv. kulturní relativismus a druhým kulturní imperialismus. Kulturní relativismus vychází ze zásady, že etika žádné kultury není lepší nebo horší než kultury jiné, tzn. nelze podle etických zásad jedné kultury hodnotit etické zásady kultur odlišných. Opakem je kulturní imperialismus, který nutí firmy nebo osoby, aby kdekoliv v jiných kulturách dodržovali zcela stejné etické principy jako ve své zemi.

Oba jmenované př́istupy se pohybují v extremních, nereálných polohách a jsou v praxi neuskutečnitelné. Rovněž etický universalismus je ve své podstatě nereálný, protože $\mathrm{v}$ různých kulturách se lidé hlásí $\mathrm{k}$ rozdílným etickým normám principům. Zatímco v anglosaské kultuře je tzv. nepotismus, protekce, prospěchářství, úplatkářství považováno za nemorální, kolektivistické kultury vycházející z jiných filozofických a náboženských základů považují nutnost postarat se o členy rodiny za ctnost a nutnost. Taktéž praxe předávání dárků a pozorností s cílem získat přízeň nebo výhody je $\mathrm{v}$ těchto kulturách pojímána odlišně [6]:

Jedním ze způsobu zjišťování hodnotového systému je forma dotazníku, kde lze zjistit, kterým stavům před jinými lidé dávají přednost. Velmi důležité je při sestavování dotazníků rozlišit skutečné od požadovaného. To co je žádoucí je většinou otázkou etických norem, skutečné odpovídá tomu, jak lidé vědomě jednají, když si mohou vybrat. Podle Hofsteda [11] je to, co odlišuje požadované od žádoucího dáno povahou norem, jako standardních hodnot platných pro určitou skupinu lidí. V př́ípade žádoucího je norma určená tím, co je absolutní a etický správné. V případě požadovaného, je norma dána statisticky, poukazuje na volby, které člověk činí. Kulturní relativismus tyto normy nepopírá, nýbrž zastává názor, že všechny skupiny lidí jsou si rovnocenné, nezávislé na hodnotách, které uznávají.

Jak se zdá, rozdíly mezi kulturami a přístupem $\mathrm{k}$ etice jsou jevem poměrně složitým. Nabízí se otázka, zda-li je možné je vůbec překonat a zda je to vůbec účelné a žádoucí.Zcela jednoznačně lze pouze odpovědět konstatováním, že k pochopení odlišnosti je zapotřebí znalostí z různých vědních oborů, jako jsou lingvistika, etnografie, antropologie, historie, 
psychologie aj. Jednoznačně žádoucí je tyto jevy monitorovat, pomocí empatie se jim snažit porozumět a posléze je popsat a v podnikatelské praxi respektovat[10]:

Je zřejmé, že se do budoucna bude stále diskutovat o universalismu kulturních a etických standardů v souvislostí s transformací ekonomik na tržním principu. Nabízí se otázka, zda tyto univerzálie jsou národního charakteru nebo zda naopak jdou napříč mnohým kulturám vzhledem ke specifickému historickému a ekonomickému období. Je možné předpokládat, že vliv tržního prostředí v zemích střední a východní Evropy bude tyto země přibližovat anglosaským standardům. Osvojování interkulturní kompetence bude muset tyto procesy reflektovat.

\section{Kultura a jazyk}

Zájem o jazyk hodnot pramení z humanistických a kognitivních přístupu k lingvistice. Analýza evaluativní složky jazyka doplňuje obecné poznatky o člověku a pro samotného jedince stanoví významný poznávací prvek v hierarchii hodnotových systémů, pomáhá v rozhodování, např. v konfliktech hodnot.

Kognitivní lingvistika považuje jazyk za formu poznávání skutečnosti, klade důraz na těsné propojení jazyka a mechanizmů jeho změn, principů složení jeho prvků aj. - s poznávacími schopnostmi člověka, jeho pocity a způsoby hodnocení.

Výsledkem pojmenování určité entity není pouze její označení, přiřazení myšlenkového obsahu, nýbrž také vyjádření vztahu mluvčího k obsahu, hodnocení, postoj odmítnutí či akceptace, vyjádření stupně skutečnosti, možnosti, pravděpodobnosti aj. Význam je pak ta část jazykového znaku, které je korelována formě, obohacená o pojmové, popř. i nepojmové složky další, a uložená jako odraz reality ve vědomí resp. paměti člověka. Význam textový se ovšem v řadě ohledů liší od významu jazykového. Má na něj vliv celá řada faktorů situačních, kontextových, presupozice aj.

Kvalifikací rozumíme takový typ pojmenování, jeho povaha je výrazně pragmatická, evaluativní, a to $\mathrm{v}$ tom, že spolu s pojmenováním určité entity implicitně, popř. explicitně vyjadřuje i její hodnocení.

Registr kvalifikujících prostředků, které má jazyk k dispozici, lze dělit na prostředky systémové /konvenční/ a textové /fakultativní závislé na kontextu/.

Dále je možno vyčlenit prostředky parajazykové /gesta, intonace, grafické symboly/ a také jazykové /flexivní, syntaktické, lexikální/ systémové nebo textové, a rovněž tropy, stylistické figury, frazeologismy, tzn. prostředky, které jsou prríznačné pro poetickou funkci jazyka.

Evaluaci formou pojmenování určité entity a také výskyt evaluativních prostředku na rovině morfologicko-syntaktické lze považovat za kódový, systémový prvek. Evaluační funkci nabývají ale rovněž jazykové prostředky v souvislosti s konsituací a kontextem. Tyto prostředky jsou obecně pokládány za textové prostředky. Hranice mezi systémovými a textovými prvky není ve většině prrípadů přesně vymezena. Lze tedy hovořit pouze o typech, o množinách, kde dochází ke vzájemným průnikům. 
Základním jazykovým prostředkem k vyjádření hodnoty jsou slova. Hodnotící prvky mohou zaujímat různé pozice $\mathrm{v}$ jejich významové struktuře. /slova mohou být bud' primárně hodnotící, tzn. že obsahují hodnotící semém jako součást základního významu lexikální jednotky /např. hodnota, dobrý, zlý/, která zahrnují hodnotící prvek současně s prvkem popisným v rámci jednoho lexému.

Neznalost a nerespektování kulturních hodnot může být ve svém důsledku pro mezinárodní marketing velmi negativní dopad. Mezi marketingem a kulturou existuje přímá závislost. Marketing z kultury vychází a zpětně ji ovlivňuje. Snaží se chápat chování zákazníků v závislosti na jejich kulturních hodnotách a standardech. Kulturní rozdíly se projevují $\mathrm{v}$ běžném životě $\mathrm{v}$ různých oblastech lidské interakce. Nejčastěji je k nim řazen verbální a neverbální komunikace, náboženství, státní organizace, politika, vzdělávání, chápání času a prostoru, zvyky a tabu, maskulinita versus feminita, vztah $\mathrm{k}$ moci, individualismus versus kolektivismus aj.

Ke vzájemnému kontaktu kultur, zprostředkování hodnot a standardů, dochází v prvé řadě prostřednictvím jazyka. Významnou úlohu zde hraje angličtina jako „lingua franca“ ve svých bezpočetných varietách. Mnohé státy se tomuto trendu snaží čelit dokonce zákonnou cestou, např. typickým představitelem je Francie, která se brání přílivu anglosaské kultury zejména v médiích, kde je povinnost dávat přednost domácím názvům před cizími. S invazí angličtiny se potýkají i severské země, Japonsko a Itálie. V německém tisku probíhají kampaně za uchování čistoty jazyka.

\section{Vyučování kultuře}

Tradiční přístup ve vyučování cizím jazykům omezoval vyučování kultuře pouze na transfer informací o lidech z cílové kultury, zvláště o jejich postojích a názorech. Hlavními používanými pojmy byla rodilá kultura $\mathrm{C} 1$ nebo cílová kultura $\mathrm{C} 2$. V poslední dekádě lze zaznamenat posun v pohledu na vyučování jazyku a kultuře a lze vymezit několik trendů, které se ve zmíněné oblasti objevily:

\section{Zavedení interkulturní sféry}

Porozumění cizí kultuře vyžaduje uvedení této kultury do vztahu se svou vlastní kulturou. Interkulturní přístup $\mathrm{k}$ vyučování kultuře je zcela odlišný od pouhého přenosu informací z jedné kultury do druhé, protože zahrnuje reflexe týkající se jak cílové tak vlastní kultury. Tento proces je pak považován za vzdělávací proces.

\section{Vyučování kultuře jako rozdílu}

V souvislosti s obnovou nacionalistických trendů a otázek národní identity na celém světě existuje tendence vytvářet kulturní stereotypy, např. tvrzení že nějaký národ postupuje výhradně stanoveným způsobem a jiný národ postupuje jinak. Na tradiční otázky, jako např. "Co by v dané situaci udělal Angličan? Je velmi obtížné odpovědět, zohlední-li se problematika narůstající multietnicity a multikulturnosti ve společnostech různých států. Neznamená to však, že kulturní charakteristiky nejsou důležité, je však třeba je uvádět ve spojení s dalšími specifikacemi kulturních faktorů, jako je věk, pohlaví, etnické zázemí, regionální příslušnost a společenská třída. 


\section{Multidisciplinární př́istup}

Vyučování kultuře je často spojováno s akademicky uznávanými disciplínami, jako je antropologie, sociologie a sémiologie. Tato skutečnost klade na učitele cizích jazyků nutnost přihlížet $\mathrm{k}$ výsledkům studií $\mathrm{z}$ oblasti sociologie, etnografie, sociolingvistiky, které se vztahují na komunitu používající vyučovaný jazyk.

Výše uvedené body mohou být považovány za základ hlubšího porozumění kultuře a je třeba je brát v úvahu při vyučování cizím jazykům.

\section{Empatie v interkulturní komunikaci}

Fenomén empatie hraje v interkulturní komunikaci nesmírně důležitou roli.

Empatie je porozumění myšlenek a pocitů jiného jedince tím, že se jiná osoba postaví na jeho místo. Slovo empatie pochází ze staré řečtiny a je odvozováno od slova "empatheia”. Definice empatie obsahuje tři hlavní aspekty[6]:

- Získat hledisko druhého člověka vyžaduje vstoupit do jeho fenomenologické oblasti, což je obtížné, jelikož každý jedinec má fenomenologickou oblast odlišnou. Po nastolení empatie by se každý jedinec měl vrátit do své vlastní původní role, v opačném př́ípadě se jedná o soucit.

- V procesu usilování o empatii je nutné porozumět pocitům a emocím druhé osoby správně. Je třeba si uvědomit, že se jedná o dvě různé složky, a to kognitivní a emocionální. Přejímání něčí role je kognitivní záležitost, kdežto cítění stejným způsobem je emocionální záležitost, při čemž kognitivní perspektiva je předpokladem pro vytvoření emocionální stránky.

- Důležitým požadavkem v nastolení empatie je způsob, jakým je sdělována lidem, kterých se týká. Pokud není dáno najevo, že něčí pocity jsou chápány druhou osobou správně, nelze hovořit o kompletní empatii. Existují dva způsoby, jak sdělit empatickou reakci - verbálně a neverbálně, optimální je však použít oba.

\section{Sebereflexe a sebehodnocení}

Současné trendy v psychologii komunikace předpokládají na konci kurzů věnovaných výuce kultury výstup v podobě vlastního portfolia základních dokumentů spojených s hodnocením vlastní úspěšnosti po dobu interakce s jedinci odlišného kulturního zázemí nebo vlastního působení v cílové kultuře. Sebehodnocení je obohaceno o prvky sebereflexe a je výchozím bodem pro získávání dalších zkušeností, které student bude schopen po získání specifických dovedností zpracovat do podoby vlastních případových studií.

\section{Kurz Personal Development Skills fro Mobilities}

Jedním z konkrétních způsobů, jak připravit studenty na nový kulturní kontext a na řešení případných konfliktů během jejich studijního či pracovního pobytu v zahraničí je rozvíjení jejich sociolingvistické, socio-kulturní a interkulturní kompetence a vytvoření vhodného kurzu, který je zaměřen na získání dovedností ve třech vzájemně propojených rovinách potřebných pro úspěšné působení v cizích kulturách. 
V rámci FRVŠ v roce 2011 byl připraven návrh sylabu kurzu v angličtině Personal Developoment Skills for Mobilities a byl také vytvořen učební text pro tento kurz, jehož stěžejním výstupem bude vlastní portfolio dokumentů obsahující prvky sebereflexe, které bude obohacováno o další zkušenosti v budoucnosti[7]:

Hlavním cílem projektu je rozvíjet sociolingvistické, sociokulturní a interkulturní kompetence studentů směřující k uplatnitelnosti na evropském pracovním trhu. Dílčí cíle projektu se týkají shromažd’ování výukových materiálů zaměřených na interkulturní, a sociokulturní problematiku a jejich didaktizace, výběru vhodných dotazníků a sebehodnotících materiálů jako základu portfolia a procvičování sebereflexních technik, prŕípravy pilotního kurzu, a vytvoření databáze případových studií.

Zmiňovaný kurz bude prvním kurzem na OPF SU, který bude cíleně připravovat studenty na mobility v anglickém jazyce a bude obsahovat nejen stěžejní témata pro úspěšnou komunikaci v EU, v jejichž rámci budou studenti rozvíjet interkulturní kompetenci, ale také specifické dovednosti týkající se klíčových komunikačních situací ve studijní a pracovní komunikaci. Hlavní přínos kurzu však spočívá v přípravě studentů na sebehodnocení a sebereflexi v rámci portfolia, které by mělo $\mathrm{v}$ jejich budoucí profesní kariéře být zdrojem inspirace, nápravy chyb a tvorby vlastních prrípadových studií. Studenti jsou vedeni k sebehodnocení pomocí online dotazníků v angličtině týkajících se interkulturní kompetence - www.inca.questionnaires, kde lze najít portfolio tří druhů dokumentů - interkulturní dotazníky, scénaře a hraní rolí. Dokumenty jsou doprovázeny instrukcemi pro zaměstnavatela a zaměstnance, jak s dokumenty pracovat a jakou váhu mohou mít při nástupu do zaměstnání.

Nově vytvořený kurz má tedy výstup korespondující se současnými trendy v psychologii komunikace- vlastní portfolio základních dokumentů spojených s rekrutací a s hodnocením vlastní úspěšnosti po dobu působení v cílové kultuře. Sebehodnocení bude obohaceno o prvky sebereflexe a bude výchozím bodem pro získávání dalších zkušeností, které student bude schopen po zvládnutí specifických dovedností zpracovat do podoby vlastních případových studií.

Sylabus kurzu v angličtině zahrnuje následující témata rozdělená do 3 bloků:

\section{Socio-Cultural Knowledge}

1 Language and social interaction, Lingua Franca, politeness theory and pragmatics

2 Culture values and theory of cultures

3 Adaptation to target culture - acculturation and culture shock

4 Stereotypes, prejudice and discrimination

II Placement and career plan

5 Recruitment process

6 Intercultural team management

7 International negotiating

8 Public speaking

III Marketing yourself - creating a portfolio of documents

$9 \mathrm{CV}$, a letter of application and a covering letter 
10 A videotaped presentation in front of the class with the following analysis

11 Working with self-evaluating documents and questionnaires

12 Creating an own case study and presenting it to the class

13 Revision.

Cílovou skupinou jsou studenti denního bakalářského studia na OPF SU, studenti kombinovaného studia a univerzity 3. věku, a také zahraniční studenti, kteří studují na OPF SU v rámci programu Erasmus.

\section{Závěr}

Dialog kultur získává na začátku 21. století status životního, politického a ekonomického imperativu. Je třeba překonat naivní a škodlivou myšlenku, že všechno národní je správné. Interkulturní kompetence je schopnost pochopit specifické rysy jiných kultur. Při interkulturní interakci se dostavuje kulturní šok, který by měl být pojímán jako oboustranné úsilí vedoucí $\mathrm{k}$ empatii.

Ukazuje se, že vyučování kultuře nelze již chápat pouze strukturalisticky jako transfer informací o lidech z cílové kultury, nebot' pojem národní kultura není monolitický, ale je v období postmodernismu a poststrukturalismu značně diferencován. Vzdělávací proces by měl v prvé řadě reflektovat vzájemné vztahy mezi domácí a cílovou kulturou. Prezentace a proskripce kulturních dat by měla být chápána procesuálně, s důrazem na pochopení odlišnosti z hlediska interkulturních aspektů. Kulturní aspekty je třeba uvádět v souvislosti s dalšími kulturními faktory, jako jsou věk, pohlaví, etnické zázemí, regionální př́íslušnost, společenská třída, kulturní hodnoty, jazyk a další. Vyučování kultuře je proto třeba vnímat multidisciplinárně, jako prolínání několika hledisek a přístupů. Kulturní mýty byly po staletí vytvářeny a kodifikovány v literární produkci a v současné době jsou vytvářeny médii. Vyučování kultuře je o to obtížnější, že kulturní mýty a reality si vzájemně odporuji, ale současně na sebe vzájemně působí. Tuto skutečnost je proto třeba akceptovat a zároveň ve vyučování kultuře reflektovat.

\section{Literatura:}

[1] BIRWHISTELL, R.L. Kinesics and Kontext, Harmondsworth, Penguin, (1967) p.198

[2] BOBÁKOVÁ, H., HEINZ, K. Linguistic and Socio-Cultural Students' Awareness Related to Communication in the EuropeanUnion In: 6th International Scientific Symposium on Business Administration, Conference Proceedings, Karviná May 27-28, 2010, p.665-674. ISBN 978-80-7248-594-9.

[3] GRENZ, S.J. Úvod do postmodernismu, Wm.B.Edermans Publishing Co. Praha 1997, s.160-182. ISBN 80-85495-74-0.

[4] HALL, E.T., WHYTE, W.F. Intercultural Communication. In: Communication and Culture, University of Oregon 1966, p.63-64.

[5] FAROLAN, E., HEINZ, K Intercultural Communication Lectures , Karviná 2002, p.414. ISBN 80-7248-162-2.

[6] HEINZ, K., ORSZULIK, I. Vyučování kultuře v kontextu postmodernismu a interkulturní pragmatiky In: Wielowymiarowość zarządzania i komunikacji społecznej w szkole pod redakcją K.Czerwińskiego, J.Kubiczka i B.Kutrowskiej, Wydział 
Zarządzania i Komunikacji Społecznej,Uniwersytet Jagielloński Kraków, str. 313-338. ISBN 978-83-7611-757-7.

[7] HEINZ, K., ORSZULIK, I. New Trends in Developing Socio-Cultural and Intercultural Competence In: World Universities Congress Proceedings I, 20-24 October 2010 Canakkale,. Turkey , p. 172-180, Pozitiv Printing Co.Ltd. Ankara Turkey.ISBN 978-605-4222-02-7.

[8] HEINZ, K. The Development of Intercultural Competence within the International Project PEACE - Grundtvig 2 In: 6th International Scientific Symposium on Business Administration, Conference Proceedings, Karviná May 27-28, 2010, p.682-687. ISBN 978-80-7248-594-9.

[9] HEINZ, K Intellego. Studia Oeconomica, vědecká monografie SU OPF Karviná, 2004, p. 7-21, ISBN 80-7248-248-X.

[10] HEINZ, K., ORSZULIK, I. Ethics and Etiquette in International Business Communication (in the intercultural preparation of students in School of Business Administration, Silesian University). In The Competetion Power Of The European Union After The Enlargement. Turkey: Gelibolu, Canakkale, 2004, s. 213-226. ISBN 9758100394.

[11] HOFSTEDE, G. Culture's Consequences, Sage Publications Beverly Hill, London, New Delhi, Second Edition, UK 2011, p. 423-454. ISBN 978-0-8039-7324-4 .

[12] KOSTOMAROV, V.G. Russkij jazyk v sovremennom dialoge kul'tur. In: Russkij jazyk za rubežom 3/1999, str. 154, Moskva 1999.

[13] LAKOFF,G., JOHNSON, M. Metaphors We Live By. TheUniversity of Chicago Press, Chicago and London, 1980.

[14] ORSZULIKOVÁ, I. Frazeologismy z hlediska interkulturních vlivů. In: Lingua et communicatio in spaera mercaturae. Luhačovice, 2004, s. 105-109. ISBN 80-7368-026-2.

[15] ORSZULIKOVÁ, I. Etické a lingvistické aspekty jazyka hodnot. In: Acta academica karviniensis 2002, I. vyd. Karviná: SU OPF, 2002, s. 219-225. ISSN 1212-415X.

[16] ORSZULIKOVÁ, I. Výzkum sémantických jednotek z oblasti podnikatelské etiky. In: Sborník výzkumných prací ÚMSP SU OPF. Karviná: SUOPF, 2002, s. 244-252. ISBN 80-7248-175-4.

[17] ORSZULIKOVÁ, I. Kulturní a jazyková diverzita ve společném evropském prostoru. In Sborník výzkumných prací Ústavu malého a středního podnikání. Karviná: SU OPF, 2003, s. 250-256. ISBN 80-7248-216-5.

[18] VEREŠČAGIN,J.M., KOSTOMAROV, V.,G. V poiskach novych putej razvitija lingvostranovedenija, str. 31-50, Moskva 1999.

\section{Klasifikace JEL: Z10}

PhDr. Krystyna Heinz, Mgr. Irena Orszulik, Ph.D.

Katedra společenských věd

SU OPF

Univerzitní nám. 1934/3

73340 Karviná

heinzova@opf.slu.cz,orszulikova@opf.slu.cz 